\title{
Odontomák diagnosztikus és terápiás aspektusai a maxillofaciális sebészetben
}

\author{
DR. SZÜTS JUDIT, DR. NÉMETH ZSOLT
}

\begin{abstract}
A különböző tanulmányok az odontomákat a leggyakoribb odontogén daganatok közé sorolják. A WHO besorolás szerint az elváltozás a benignus daganatok közé tartozik, azonban más nézetek alapján inkább hamartomának tekinthető. A tanulmány célja a hazai és külföldi szakirodalmat alapul véve az odontomákhoz kapcsolódó információk összefoglalása, fókuszálva az elváltozás diagnosztikus és terápiás módjaira.

Az odontomák pontos eredete ismeretlen. Néhány teória szerint bakteriális és virális infekciók, trauma, mutációk és abnormális gének is vezethetnek odontomaképződéshez. Gyakran alakulnak ki odontomák örökletes szindrómák (Gardner-, Hermann-, Gorlin-Goltz- és otodentális szindróma) részeként is.

Leggyakrabban az első két évtizedben jelennek meg, nemi eloszlás tekintetében nem mutatnak különbséget. Különféleképpen csoportosíthatjuk az odontomákat, a leggyakoribb a WHO klasszifikáció, amely szerint két típust különböztethetünk meg: a compound odontomát és a complex odontomát. Diagnosztikájuk kiegészítő vizsgálatok nélkül meglehetősen bonyolult lehet, ugyanis tünetszegények, a fogazat rendellenességei, impakció, retenció, duzzanat és/vagy aszimmetria utalhat csak a jelenlétükre. Általában röntgenfelvétel során kerülnek felfedezésre, pontos diagnózisuk csak hisztopatológiai vizsgálat után mondható ki.

Az odontomák terápiája sebészi eltávolítás, ami történhet extraorális és intraorális megközelítésből is. A műtét során egyre gyakoribb a modern készülékek (lézer, ultrahangos/piezo-/ sebészet) használata. Szövődményekre a legtöbb esetben nem kell számítani.
\end{abstract}

Kulcsszó: odontoma, odontogén daganat, jóindulatú daganat, complex odontoma, compound odontoma

\section{Bevezetés}

A különböző tanulmányok az odontomákat a leggyakoribb, jóindulatú odontogén daganatok közé sorolják, azonban elterjedt az a nézet is, hogy az elváltozások inkább hamartomának felelnek meg. Általában fiatal korban fedezik fel ezeket, jellemzőjük a lassú növekedés, tüneteket nagyon gyakran nem mutatnak de deformálhatják a csontokat, fogakat, megakadályozhatják a maradó fogak előtörését, ezért korai felismerésük és kezelésük fontos feladat $[10,26]$.

Az odontoma szó Paul Broca nevéhez köthető, aki 1867-ben alkotta meg ezt a kifejezést fogszövetekből álló tumorra vonatkoztatva. Pierre Fauchard volt az első, aki pontos leírást adott az odontomáról. Az első complex odontomáról szóló cikk 1848-ban jelent meg az American Journal of Dental Science címú folyóiratban, compound odontomáról pedig az 1850-es évek közepén írtak először [21, 34].

\section{Etiológia}

Az odontomák pontos eredete ismeretlen. A különböző szerzők azt valószínúsítik, hogy létrejöttükben nagy szerepet játszanak a külső, környezeti és belső, genetikai tényezők.

Külső tényezők közé soroljuk a helyi traumákat és a vírus vagy baktérium okozta infekciókat. Helyi képletek nyomása (pl. tejfogak gyökerei) és külső trauma (luxatio, avulsio) is hatással van a fogcsírára, egyes esetekben odontomaszerú képletek jöhetnek létre (Glasston, Rushton és Levy ezt kísérlettel bizonyította). Ennek az az alapja, hogy a malformatio az odontogenezis korai fázisában történik és az ameloblast-fejlődés morfogenetikus fázisára van hatással. Az elváltozás kiindulási sejtjei a különböző kutatások alapján valószínűleg az érett ameloblastok, a dentális lamina maradványai és az odontogén epitheliális sejtek 38].

Genetikai tanulmányok alapján kijelenthető, hogy a géneket szabályozó mechanizmusok zavarának, a gének mutációinak vagy az abnormális gének öröklődésének is lehet odontoma a következménye. Egy 2015-ös vizsgálat eredményeként kimutatták, hogy a WNT (Wingless-related integration site) szignalizációs útvonal aktiválására fogszerū képletek jöttek létre. A cikkben rágcsálókkal kísérleteztek. A SOX2 expresszáló sejtek B-catenint expresszálnak, ami a WNT útvonalat aktiválja számos őssejtben és pluripotens sejtben. Azon- 
ban ha mutáns B-catenint képeztek a sejtek, akkor az számos fogszerú képletet hozott létre az egerekben, ami nagyon hasonlított az emberi odontomára [49]. Nagyon gyakran örökletes szindrómák (Gardner, Hermann, Gorlin-Goltz, otodentalis szindróma) részeként is megfigyeltek odontomaképződést [3, 15, 35].

\section{Epidemiológia}

Tanulmányok sokasága vizsgálta világszerte az odontomák epidemiológiáját. Ezekről egységesen elmondható, hogy a kutatások a leggyakoribb odontogén daganatok közé sorolják a fent említett elváltozást: Hidalgo Sánchez metaanalízise az első, Taghavi, Olgac és Fernandes tanulmánya a második, Jing pedig a harmadik leggyakoribb odontogén daganatként említi az odontomákat [20, 44]. Életkori megoszlás tekintetében a fiatal kortól idős korig megjelenhetnek, de legfőképpen a fiatal felnőtt korosztály érintett $[8,19,20,44]$. A két nem közötti előfordulás tekintetében a tudományos cikkek többsége nem talált eltérést, nőkben és férfiakban is ugyanolyan gyakran fordul elő $[8,20]$. Ettől eltérő eredményre jutott Taghavi, aki szerint a nőkben gyakoribb az elváltozás (59,3\%) [44]. Az odontomák típusaival is foglalkoztak a kiadványok: a compound odontoma előfordulása kétszer olyan gyakori volt, mint a complex odontomáé [19, 20].

\section{Patológia}

Az odontomák az odontogén daganatok, azon belül pedig a jóindulatú daganatok közé sorolhatók [32]. Különböző fejlettségú fogszövetet: zománcot, cementet és dentint tartalmaznak. Többféleképpen csoportosíthatjuk az odontomákat: a felosztás évtizedenként és könyvenként változik.

Thoma öt alcsoportra osztotta az elváltozást: az odontoma compositum geminatumra, melyben két vagy több egybeolvadt fogat figyelhetünk meg; a compound composite odontomára, mely csökevényes fogakból áll; a complex composite odontomára, amely rendezetlen megjelenést mutat; az odontoma dilatatumra, mely nagyon ritka és amelyben vagy a korona vagy a gyökér

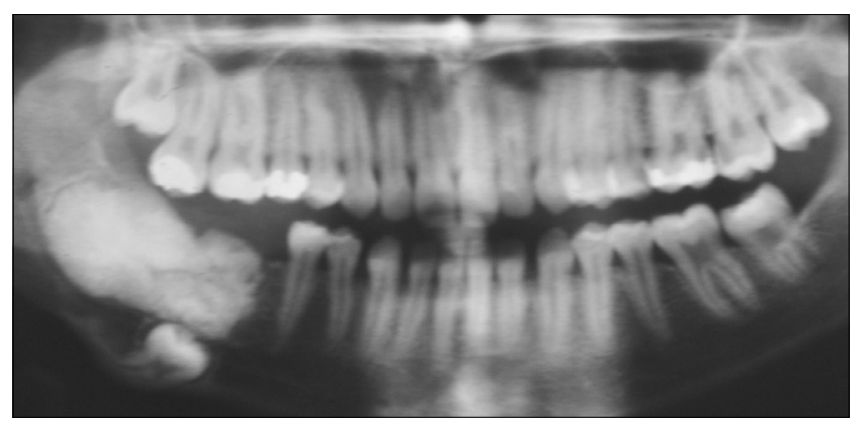

1. kép: Odontoma compositum complexum a mandibula jobb oldali moláris területén jelentősen megnagyobbodott; és végül a cisztás odontomára, ahol az odontoma vagy a cisztában vagy a ciszta falában jelenik meg [45].

Ferenczy a Fogászati radiológia címú könyvben egy Thomáéhoz hasonló felosztást használ: megkülönbözteti az odontoma compositum conglobatumot, az odontoma compositum complexumot (1. kép), az odontoma compositum geminatumot, és az odontoma compositum dilatatumot. Ötödik csoportként azonban az elözővel ellentétben nem a cisztás odontomát, hanem az odontoma compositum gestatumot említi, ahol a fog belsejében egy fogszerú képlet van [11].

Gorlin három alcsoportot különböztet meg: a complex és a compound odontomát és az odontoameloblastomát. Az utolsó csoport ameloblastoma és odontoma egy idejú jelenlétét mutatja [16].

Szabó György is három alcsoportot mutat be: az odontoma compositum conglobatumot, az odontoma compositum complexumot és az odontoma compositum cysticumot 43].

A legelterjedtebb besorolás azonban a fentiekkel ellentétben a WHO klasszifikáció, amely két típusra osztja az odontomákat: compound odontomákra és complex odontomákra. A compound odontomákra jellemző, hogy a bennük lévő szövetek nem térnek el jelentősen az egészséges fogszövetektől, de azok mérete és formája jelentősen különbözik a normálistól. Az elváltozás kis fogak halmazára hasonlít. Sokkal gyakoribb elváltozás, mint a complex odontoma és a maxilla elülső régiójában fordul elő leggyakrabban. Ezzel szemben a complex odontomában a fogszövetek rendezetlenül helyezkednek el, amorf képet adva az elváltozásnak, semmilyen anatómiai egyezést nem mutatnak a fogakkal. Leggyakoribb előfordulási helye a mandibula hátsó régiója, de előfordul a maxilla elülső régiójában is $[32,48]$.

A fent említett klasszifikáción kívül más szempontok szerint is osztályozhatjuk az elváltozásokat. Csoportosíthatjuk őket eredetük szerint: vannak epithelialis, composite (epithelialis és mesodermalis) és kötőszöveti formák is. Állcsontban való elhelyezkedésük alapján pedig két alcsoportot különböztethetünk meg: intraossealis típust, mely a csonton belül helyezkedik el és elő is törhet a szájüregben, illetve az extraoralis vagy perifériás típust, ahol az odontoma lokalizációja a lágyszövetben van [38].

\section{Diagnosztika}

Anamnézis, klinikai vizsgálat

A páciensek anamnézisét tekintve általában nem találunk szignifikáns eltérést, nagy részük teljesen egészséges, panaszmentes. Genetikai szindrómák részeként is jelentkezhet az elváltozás, gyakran előfordul Gardner-, Gorlin-Glotz-, Hermann- és otodentális szindrómában szenvedő páciensekben.

Az odontomák diagnosztikája nehéz, nincsen specifi- 
kus tünetük, jelentős panaszokat nem okoznak. A fogazat rendellenességei (impakció, retenció, malocclusio, foghiány) és a nyálkahártya elszíneződése utalhat a jelenlétükre [14, 18, 36, 38, 47]. Gyakran palpációval is tapasztalhatjuk az elváltozást: általában csontkemény tapintatú terimét érzékelhetünk [31], cysticus odontoma esetén azonban fluktuáció jelentkezhet [6]. Ritka esetben az odontoma transmucosalis áttörést mutat a szájüregbe: sárgás-barnás fogszövet szerű elváltozást láthatunk, ami torz fogakra emlékeztet [1, 4].

A betegek egy része fájdalom miatt keresi fel kezelő orvosát, gyakori még a rágóképesség csökkenése is. Nagyobb méretű odontomák az állcsontot felfújják, deformációt okoznak, amelynek hatására az arc aszimmetrikussá válik, bőre megfeszül [18, 22, 31, 36, 47].

Ritka esetben az odontoma ectopiás elhelyezkedést is mutathat. Írtak le már például odontomát az orrüregben is, a páciens orrfolyásról, orrjárat-elzáródásról, kellemetlen szagokról panaszkodott, szélsőséges esetben rhinosinusitishez is vezetett az elváltozás [30].

\section{Röntgen}

Az odontomák többsége más okból elvégzett röntgenvizsgálat során, véletlenszerūen kerül felismerésre. Ezzel az olcsó és széles körben elterjedt noninvazív eljárással viszonylag egyszerūvé válik az odontomák diagnosztikája, sőt típusainak elkülönítése is. Leggyakoribb felvétel a panorámafelvétel (OP), de intraorális felvételt is készíthetünk, ha nagyobb felbontású, részletesebb képre van szükségünk. Compound odontoma röntgenképén viszonylag szabályos elrendeződést figyelhetünk meg: torz fogakat vagy fogszerú képleteket láthatunk. Az elváltozás fejlődési stádiumának elkülönítésére is van lehetőség. A teljesen kifejlődött laesiót legtöbbször elég könnyű diagnosztizálni, azonban a fejlődő odontoma detektálása már lényegesen nehezebb feladat. Korai állapotban csak egy jól elhatárolt osteolysis figyelhető meg, később már láthatóvá válnak a fogszerú elemek, széles radiolucens zónával körülvéve. A késői stádiumokban már csak egy keskeny radiolucens zónát látunk, ami kevésbé jól elhatárolt. Ezzel szemben a complex odontoma rendezetlen, ovális alakú, radiopaque elváltozásként jelentkezik radiológiai vizsgálat során, melyet vékony, határozott radiolucens zóna vesz körül. Ez a forma is tartalmaz minden alapvető fogszövettípust, csak nem rendezetten, hanem amorf massza képét mutatva [33].

\section{CT/CBCT (Cone Beam Computed Tomography)}

Napjainkban modern radiológiai eljárásokat is alkalmaznak az odontomák pontosabb diagnosztikájához. Ezek azonban legtöbbször csak térítés ellenében vehetők igénybe és az elváltozások pontosabb lokalizációjában (pl. mútét tervezésében) játszanak szerepet. Az odontomák a CT-n, illetve a CBCT-n is radiopaque megjelenést mutatnak, körülöttük radiolucens szegély figyelhető meg (2. kép). A CT hazánkban ingyenes, azonban kevésbé részletgazdag, főként az alsó áll-

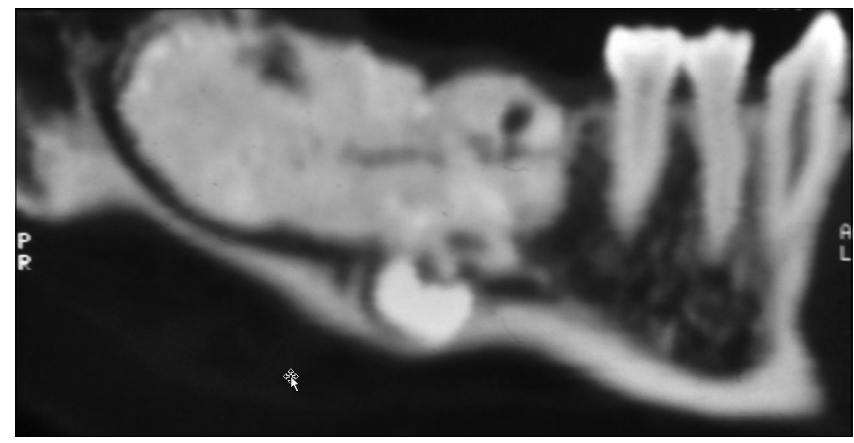

2. kép: A CT felvételen jól látható az odontoma, a diszlokált moláris fog és a canalis mandibulae lefutása

csonton. A CBCT modernebb, gyorsabb, kisebb sugárterheléssel járó technika, ami nagyon hasznos lehet a sebészi eltávolítás megtervezésében. Hátránya azonban, hogy Magyarországon az eljárás nem térítésmentes $[35,39,40]$.

Új lehetőségeket kínálhat a micro-CT, amely háromdimenziós analízist tesz lehetővé. Szövettani vizsgálathoz hasonlóan lehet vele az elváltozásokat értékelni, anélkül, hogy a mintát előkészítettük volna. Ez a technológia azonban gyakorlatban még nem terjedt el, egyelőre csupán kutatásokban használják. További fejlesztéssel a micro-CT a jövő fontos diagnosztikus eszköze lehet $[37,42]$.

\section{Hisztológia}

Az eltávolított odontomát minden esetben szövettani vizsgálatnak kell alávetni. Sokszor csak ez alapján tudunk egy-egy elváltozásról pontos diagnózist adni. Az odontomákból vékony szeleteket képeznek, megfelelően előkészítik, így a metszeteket mikroszkóppal vizsgálhatóvá teszik [50].

Mikroszkópos vizsgálat során a complex odontomák körül egy fibrosus tokot figyelhetünk meg. Maga az elváltozás zománcból, cementből és dentinből áll, ezek a szövetek egy kiterjedt képletet hoznak létre, aminek az elrendeződése eléggé szabálytalan. A zománc egy része teljesen kalcifikált, azonban egy-két részen látni lehet a zománcmátrixot is. A zománcprizmák könynyen felismerhetők, látni lehet a Retzius-féle vonalakat, zománclemezeket, zománcorsókat és zománcrojtokat is. Az odontomákban a legnagyobb arányban előforduló szövet a dentinszövet. Felépítése általában megegyezik a fogakban lévő dentinszövettel: felismerhetők a tubulusok, a primer és secundaer dentin, az interglobularis dentin és a Tomes'-féle szemcsés réteg. Az Ebner-féle növekedési vonalakat is észrevehetjük. Pulpaszövethez hasonló szövet és cement is jelen van az elváltozásban.

A compound odontoma is fibrosus tokban helyezkedik el, benne számos különálló fogat vagy fogszerú képletet találunk fibrosus szövetbe ágyazva. Gyakran a fogacskák körül csontszöveti trabeculákat is láthatunk. Mind makroszkóposan, mind mikroszkóposan rendkí- 
vüli hasonlóságot mutatnak a fogakhoz: alakjuk a fogakhoz hasonló és zománcból, dentinből, cementből, pulpából állnak, csak kismértékben térnek el a normális szövetektől [9, 12, 17, 24, 27, 41].

Modern szövettani vizsgálati módszerek is egyre jobban elterjedtek a diagnosztikában. Confocalis Laser Scanning Mikroszkóppal (CLSM) is vizsgálták az odontomákat. Ezzel a módszerrel autofluoreszcencia alapján elkülöníthetők a fog szövetei: a dentin magasabb fluoreszcenciával rendelkezik mint a zománc, a dentin magasabb kollagéntartalma miatt. A szellemsejtek kimutatása is könnyú ezzel a módszerrel [25, 28].

Pásztázó elektronmikroszkóp használatára is volt példa az odontomák vizsgálata során: a technika előnye, hogy segítségével láthatóvá válnak a zománcprizmák, a perikymaták és Tomes' nyúlványok lenyomatai [23].

\section{Differenciáldiagnózis}

Az odontomákat tünetszegény és aspecifikus megjelenésük miatt számos más betegségtől kell elkülönítenünk. Néha teljesen más jellegú betegséghez hasonló képet is mutathatnak, ezért csak alapos vizsgálatok után mondhatjuk ki a végső diagnózist. El kell különítenünk a fibro-osseus laesióktól, a kalcifikáló odontogén tumortól, a fibrosus dysplasiától és a krónikus osteomyelitistől. Számos más odontogén daganat is mutat odontomához hasonló képet: ilyen az ameloblastos fibróma, az ameloblastos fibroodontóma, az odontoameloblastoma és a kalcifikáló odontogén tumor. Differenciál diagnosztikai szempontból fontos még megemlíteni a jóindulatú daganatok közül az osteomát, az osteoblastomát és a cementomát is. A számfeletti fogak és az impaktált fogak odontomáktól való elkülönítése is néha meglehetősen bonyolult lehet 1, 5, 8, 14].

\section{Terápia}

\section{Mütéti technikák}

Az odontomák terápiája minden esetben a sebészi eltávolítás. Tünetszegény esetben dönthetünk a sebészi eltávolítás mellőzése mellett is, azonban célszerū a pácienst időközönként kontrollra visszahívni.

\section{Konvencionális eljárások}

Az odontomák eltávolítása kétféle módon történhet: intraorális megközelítésből, illetve, ha az elváltozás a mandibulában nagy kiterjedést mutat, akkor az extraorális megközelítés a megfelelő hozzáférés érdekében előnyösebb lehet. A legtöbb enucleatio gyors folyamat és nem igényel speciális előkészítést: a fogorvosi rendelőben, helyi érzéstelenítésben végrehajtható. Azonban kiterjedtebb elváltozásoknál már célszerű általános érzéstelenítés mellett végrehajtani a beavatkozást, majd kórházi ellátásban részesíteni a pácienst. Az elváltozások eltávolítása után a kialakult üreget körültekintően át kell vizsgálni, meg kell győződni arról, hogy a tumorszövet teljes egészében eltávolításra került. Ennek

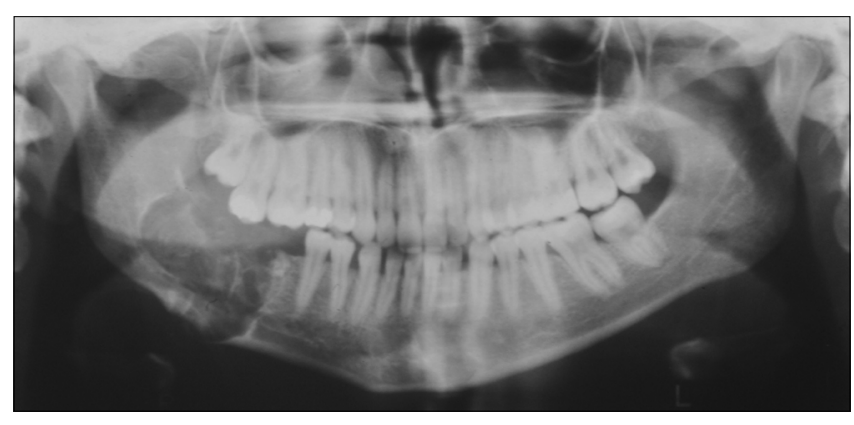

3. kép: Kontroll OPG. A képlet eltávolítását követően a csontdefektust spongiosa forgáccsal töltötték fel.

érdekében röntgenfelvétel készítése is célszerü lehet (3. kép). Ha a mútét intraorális feltárásból történt, akkor a mucoperiosteális lebenyt visszafektetjük a helyére. Kiterjedt defektusok esetén csontpótló eljárásokat is alkalmazhatunk, végül suturával zárjuk a mútéti sebet. Extraorális feltárás esetén a sebszélek réteges zárása javasolt, nyomókötés felhelyezése is célszerü lehet [46].

\section{Modern technikák}

A konvencionális eltávolítás mellett egyre elterjedtebbé válik a modern technika, ami számos előnnyel rendelkezik. Alkalmazása során egyszerübbé és gyorsabbá válhat a mútét kivitelezése, kevésbé traumatizál, csökkentheti a kezelés utáni szövődményeket. Hátrányai közé elsősorban a készülék magas árát soroljuk.

Az egyik ilyen technika az ultrahangos (piezo-)sebészet, amely jelentősen csökkenti a környező szövetek károsodásának esélyét. Használatával minimalizálhatjuk az erek, a fogszövetek és a nervus alveolaris inferior sérülését. A technika lehetővé teszi a csontszövet szelektív vágását, nagyfokú precizitással, vérzésmentesen végezhetjük a mútéteket $[7,13]$.

A lézer alkalmazása is egyre elterjedtebb a szájsebészetben, odontomák eltávolítására is használható. A leggyakrabban használt lézerek az Er:YAG (erbium-doped yttrium aluminium garnet laser) és az Er,Cr:YSGG (erbium, chromium: yttrium-scandium-gallium-garnet laser) [2, 29].

\section{Posztoperatív teendők}

A mútét után a pácienst utasítani kell a seb tisztántartására, öblögetők rendelése kötelező. Jelentős arcduzzanat 3-4 napos hideg borogatással, jegeléssel megelőzhető, megszüntethető. Láz esetén lázcsillapító adása javasolt, azonban felmerül a felülfertőződés esélye is, ezért általában antibiotikumot is írunk fel a betegnek. Extraorális feltárásból végzett mútét esetén a sebüregben Redon-draint hagyunk a haematomaképződés megelőzésére [46].

A pácienseknek az előírt diétát kell tartaniuk (intraorális mútétek esetén tejmentes étrend), kerülni kell az erőteljes rágást igénylő ételeket, illetve vitamin- és proteindús ételek fogyasztása javasolt [46]. 


\section{Szövődmények}

Odontoma eltávolítása után ritkák a szövődmények. Felülfertőződésre lehet esetleg számítani, amit antibiotikus terápiával, illetve lokális irrigációval gyógyítunk. Egy másik szövődmény az állcsont törése, amely a csont meggyengülése miatt következhetik be, akár kisebb mozdulatok hatására is. A törést intermaxillaris fixatióval vagy az állcsont minilemezes osteosynthesisével látjuk el. Ha az odontomák gyermekkorban jelennek meg, akkor azok eltávolítása után előfordulhat, hogy az odontoma helyén előtörő maradó fog rendellenes megjelenésủ lesz. Egy követéses vizsgálatban moláris tejfoggal összefüggő odontoma eltávolítása után a később előtörő premoláris maradó fog tejmolárisszerű alakot vett fel [46].

\section{Megbeszélés}

Az odontomák a leggyakoribb odontogén daganatok közé tartoznak. A WHO a benignus daganatok közé sorolja, azonban elterjedtebb az a nézet, hogy inkább fejlődési rendellenességnek tekinthetők. Főleg a fiatalabb korosztályt érinti a megbetegedés, legtöbbször a 20-40 éves korosztály érintett. Nagyon fontos az elváltozásokat helyesen és időben diagnosztizálni. A klinikai vizsgálat során általában lényeges eltérést nem találunk, nagy többségük csak radiológiai vizsgálattal kerül felismerésre. Legbiztosabb diagnózist azonban a szövettan alapján lehet adni. Az odontomák terápiája minden esetben a sebészi eltávolítás, ami történhet konvencionális módon vagy modern technikával. Szövődményekre általában nem kell számítani, ritkán felülfertőződés vagy állcsonttörés lehetséges.

Napjainkban is számos tanulmány készül az odontomákkal kapcsolatban. Lassú, folyamatos növekedésük miatt fontos a minél elóbbi diagnosztikájuk, ugyanis a nagy méretű odontomák jelentős deformációkat, malocclusiót okozhatnak, akadályozhatják a fogak elötörését. Ezek alátámasztják, hogy jelentőségét nem szabad alábecsülni, mihamarabbi terápia szükséges.

Anyagi támogatás: A közlemény anyagi támogatásban nem részesült.

Érdekeltségek: A szerzőknek nincsenek érdekeltségeik.

\section{Szerzői munkamegosztás:}

SZJ: a dolgozat elkészítése, irodalomgyújtés, kézirat megszövegezése

NZS: a dolgozat koncepcionális strukturálása, a szöveg végső kialakítása, szupervízió

A szerzők nyilatkoznak arról, hogy ez saját munkájuk, a végleges szövegezést mindketten elolvasták, jóváhagyták.

\section{Irodalom}

1. Agrawal B, Gharote H, Nair P, Shrivastav S: Infected complex odontoma: an unusual presentation. BMJ Case Rep 2012; bcr2012006493.

2. Angiero F, Benedicenti S, Parker S, Signore A, Sorrenti E, GiACOMETI E ET AL: Clinical and Surgical Management of Odontoma. Photomed Laser Surg 2014; 32: 1, 47-53.

3. Anqi L, Meiling W, Xiaohe G, Hao G, Zhifel Z, Kewen W et al: Clinical, pathological, and genetic evaluations of Chinese patient with otodental syndrome and multiple complex odontoma: Case report. Medicine 2017; 96: 56014.

4. Avinash Tejasvi ML, Balajl Babu B: Erupted Compound Odontomas: A Case Report. J Dent Res Dent Clin Dent Prospect 2011; 5 (1): 33-36.

5. Barba lt, Campos dM, Nevárez Rascón mM, Ríos Barrera Va, Nevárez Rascón A: Descriptive aspects of odontoma: literature review. Rev. Odont. Mex 2016; 20/4: 265-269.

6. Costa V, Caris AR, León JE, Ramos CJ, Jardin V, Kaminagakura E: Cystic Odontoma in a Patient with Hodgkin's Lymphoma. Case Rep Dent 2015; 292819, 5 pages.

7. Cristalli MP, la Monaca G, Sgaramella N, Vozza I: Ultrasonic bone surgery in the treatment of impacted lower third molar associated to a complex odontoma: a case report. Ann Stomatol (Roma) 2012; 3 (2): 64-68.

8. CsIBA Á: Jóindulatú odontogén (fog eredetű) daganatok. In CsIBA Á (szerk.): Szájpatológia. Medicina Könyvkiadó, Budapest, 1987; 174-188.

9. Das UM, Viswanath D, Azher U: A Compound Composite Odontoma Associated with Unerupted Permanent Incisor: A Case Report. Int J Clin Pediatr Dent 2009; 2 (2): 50-55.

10. D’Azevedo Barros L, Rubens Utumi E, Gregnanin Pedron I, ZamBON CE, Rocha AC: Complex Odontoma: Report of a Five-year Follow-up Case. J Dent Child 2010; 77: 183-186.

11. FeRENCZY K, MartonfFy K: Patológiai röntgendiagnosztika/Daganatok/Odontoma. In MARTONFFY K (szerk.): Fogászati radiológia. Semmelweis Kiadó, Budapest, 2010; 221-223.

12. Gallatz K: A fogak anatómiája, szövettana, fejlődése, dentitio. In FeHÉR E (szerk.): Maxillofacialis anatómia. Medicina Könyvkiadó, Budapest, 2014; 49-77.

13. GÁSPÁR L: A piezoeljárás - ultrasurgery -sztomatológiai alkalmazásának alapvonalai. Dental Hírek 2011; 3: 48-53.

14. Gedik R, MüftüoĞLu S: Compound Odontoma: Differential Diagnosis and Review of the Literature. West Indian Med J 2014; 63 (7): 793-795.

15. Girish G, Bavle RM, Singh MK, Prasad SN: Compound composite odontoma. J Oral Maxillofac Pathol 2016; 20 (1): 162.

16. Gorlin RJ: Odontogenic tumors. In Gorlin RJ, Goldman HM (ed.): Thoma's Oral pathology (6th ed.). The C.V. Mosby Company, St. Louis, 1970; 481-515.

17. Govindrajan S, Muruganandhan J, Shamsudeen S, Kumar N, RamaSamy M, Prasad S: Complex Composite Odontoma with Characteristic Histology. Case Rep Dent 2013; 157614.

18. Gyulai-GaÁl Sz, Takács D, Barabás J, Tarján I, Martonffy $\mathrm{K}, \mathrm{Sz}-$ ABÓ GY ÉS MTSAI: Fogelőtörési zavarokkal járó vegyes odontogén daganatok. Fogorv Szle 2007; 100: 2, 65-69.

19. HASANUDDIN S, REDDY ER:Erupted odontome associated with a primary molar: A unique clinical presentation, 4-year follow-up. J Oral Maxillofac Pathol 2017; 21 (2): 322.

20. Hidalgo Sánchez O, Leco Berrocal im, Martínez González JM: Metaanalysis of the epidemiology and clinical manifestations of odontomas. Med Oral Patol Oral Cir Bucal 2008; 1; 13 (11): E730-734.

21. Imran A, Jayanthi $P, T$ tanveer $S$, Gobu SC: Classification of odontogenic cysts and tumors - Antecedents. J Oral Maxillofac Pathol 2016; 20 (2): 269-271. 
22. Kaneko M, Fukuda M, Sano T, Ohnishi T, Hosokawa Y: Microradiographic and microscopic investigation of a rare case of complex odontoma. Oral Surg Oral Med Oral Pathol Oral Radiol Endod 1998; 86: 1, 131-134.

23. Kerebel L-M, Kerebel B: Dysplastic enamel in odontoma: a light microscopic, microradiographic and SEM study. J Oral Pathol 1984; 13: 137-146.

24. Kulkarni VK, Deshmukh J, Reddy Banda N, Reddy Banda V: Odontomas-silent tormentors of teeth eruption. BMJ Case Rep 2012; bcr2012007666.

25. Lacarbonara M, Lacarbonara V, Cazzolla a P, Spinelli V, CrincoLI V, LACAITA MG ET AL: Odontomas in developmental age: confocal laser scanning microscopy analysis of a case. Eur J Paediatr Dent 2017; 18/1, 77-79.

26. Lone PA, Kour I, Gandral A: Intra Oral Approach for Complex \&Compound Odontomas (Large or Small). MPS 2014; 4: 35-45.

27. LuCAs RB: Odontoma. In Lucas RB (ed.): Pathology of Tumours of the Oral Tissues. (3rd ed.) Churchill Livingstone, Edinburgh, London, New York, 1976; 81-88.

28. Lucchese A, Petruzzi M, Scivetti M, Pilolli GP, Di Bisceglie MB Crincoli V et aL: Calcifying Odontogenic Cysts Associated with Odontomas: Confocal Laser Scanning Microscopy Analysis of 13 Cases. Ultrastruct Pathol 2011; 35: 3, 146-150.

29. Monteiro LS, Martins M, Pacheco JJ, Salazar F, Magalhães J Vescovi P, Meleti M: Er:YAG Laser Assisted Treatment of Central Odontogenic Fibroma of the Mandible. Case Rep Dent 2015; Article ID 230297, 6 pages.

30. Musgrave B, Stapp R, Torres F, Schweitzer V: Case Report: Ectopic Odontoma of the Nasal Cavity. Radiol Open J 2011; 1, 17-19.

31. Németh Zs, Barabás J, Hrabák K, Bogdán S, Velich N: A mandibulában kialakult nagyméretű odontoma: Esetismertetés. Dental Hírek 2005; 9: (6) 54-56.

32. Neville BW, Damm DD, Allen CM, Chi AC: Odontogenic Cysts and Tumors. In Neville BW (ed.): Oral and Maxillofacial Pathology Elsevier, 2016; 632-689.

33. Pasler FA, Visser H: Odontogenic Tumors, Hamartoma, Dysplasias/Odontoma. In PASLER FA, VISSER H (ed.): Pocket Atlas of Dental Radiology Thieme, Stuttgart, New York, 2007; 264-267.

34. PhILIPSEN HP, Reichart PA: Classification of odontogenic tumours. A historical review. J Oral Pathol Med 2006; 35: 9, 525-529.

35. Rossini Carvalho Visioli A, de Oliveira e Silva C, Carlos Marson F, MitsunaRI TAKESHITA W: Giant complex odontoma in maxillary sinus. Ann Maxillofac Surg 2015; 5 (1): 123-126.

36. Santos Costa F, Iwaki Filho L, Vessoni Iwaki LC, Jacobucci Farah
G, de Almeida Bastos Maciel A, Lima Maciel FJ: Complex odontoma: A clinical case report. Sci J Dent 2015; 2: 22-26.

37. Santos LAN, Lopes LJ, Roque-Torres GD, Oliveira VF, Freitas DQ: Complex Odontoma: A Case Report with Micro-Computed Tomography Findings. Case Rep Dent. 2016; 3584751.

38. Satish V, Prabhadevi MC, Sharma R: Odontome: A Brief Overview. Int J Clin Pediatr Dent 2011; 4 (3): 177-185.

39. Schramm A, Rücker M, Sakkas N, Schön R, Düker J, Gellrich N-C: The use of cone beam CT in cranio-maxillofacial surgery. Int Congr Ser 2005; 1281, 1200-1204.

40. Shweel M, Amer MIK, El-Shamanhory AF: A comparative study of cone-beam CT and multidetector CT in the preoperative assessment of odontogenic cysts and tumors. Egypt. J. Radiol. Nucl. Med 2013; 44: 1, 23-32.

41. Soluk Tekresin M, Pehlivan S, Olgac V, Aksakalli N, Alatli C: Clinical and Histopathological Investigation of Odontomas: Review of the Literature and Presentation of 160 Cases. J Oral Maxillofac Surg 2012; 70: 6, 1358-1361.

42. Swain MW, XUE J: State of the Art of Micro-CT Applications in Dental Research. Int J Oral Sci 2009; 1 (4): 177-188.

43. SzABó Gy: Maxillofacialis daganatok, fej-nyak daganatok/Odontogén jóindulatú daganatok. In SzABÓ Gy (szerk): Szájsebészet, maxillofacialis sebészet. Semmelweis Kiadó, Budapest, 2004; 158-160.

44. Taghavi N, Rajabi M, Mehrdad L, SaJjadi S: A 10-year retrospective study on odontogenic tumors in Iran. Indian J Dent Res 2013; 24: 2 220-224.

45. Тнома KH: Tumors of odontogenic origin/Odontoma. In Тнома KH (ed.): Oral Pathology (4th ed.). The C.V. Mosby Company, St. Louis, 1954; 1223-1233.

46. Тнома KH: Tumors of jaws of odontogenic origin/Odontoma and odontoameloblastoma. In Tнома KH (ed.): Oral Surgery (5th ed.). The C.V. Mosby Company, Saint Louis, 1969; 1030-1035.

47. Tuczyńska A, Bartosik D, Abu-Fillat $Y$, Soltysik A, MatthewsBrzozowska T: Compound odontoma in the mandibule-case study and literature review. Dev Period Med 2015; XIX,4484.

48. UMA E: Compound Odontoma in Anterior Mandible-A Case Report. Malays J Med Sci 2017; 24 (3): 92-95.

49. Xavier GM, Patist Al, Healy C, Pagrut A, Carreno G, Sharpe PT ET AL: Activated WNT signaling in postnatal SOX2-positive dental stem cells can drive odontoma formation. Sci Rep 2015; 5: 14479.

50. Zalatnal A: A patológia tárgya, célja, helye az orvostudományban: Hisztopatológia. In ZaLATNAI A (szerk.): Gyakorlati patológia. Semmelweis Kiadó, Budapest, 2014; 2-5.

\section{SZÜTS J, NÉMETH Zs}

\section{Diagnosis and treatment of odontomas in the maxillofacial surgery}

Odontomas are one of the most common odontogenic tumors. In the WHO classification they are benign tumors, although nowadays they are considered to be hamartomas instead. The aim of the review is to summarize the information of the odontomas based on publications and books, which were released recently and in the last century.

The exact etiology of the odontomas is unknown. There are several theories, which suggest that bacterial and viral infections, trauma, mutations and abnormal genes can lead to the formation of the odontomas. They are also seen in hereditary anomalies such as Gardner-, Hermann-, Gorlin-Goltz- and otodental syndromes.

Odontomas are common in the second decade of life and they don't show any gender predilections. There are several types of classifications of odontomas, the most common type is the WHO classification, which divides odontomas into two groups: compound and complex odontomas. Odontomas are asymptomatic, only tooth deformations, impaction, retention, swelling, asymmetry can suggest to its presence. They are usually diagnosed during X-ray examination, but the exact diagnosis can be told after histopathological examinations.

The therapy of the odontomas is the surgical enucleation. It can be performed from ontraoral and extraoral approach. Modern techniques such as laser and ultrasurgery can be also used during the surgery. Complications are quite rare after the operation.

Keywords: odontoma, odontogenic tumor, benign tumor, complex odontoma, compound odontoma 